\title{
REVIEW
}

\section{Understanding the Similarities and Differences between Hepatic and Pulmonary Veno-Occlusive Disease}

Sven Günther, ${ }^{*}$ Frédéric Perros, ${ }^{\dagger}$ Pierre-Emmanuel Rautou ${ }^{\ddagger \S}$ Barbara Girerd, ${ }^{\dagger 币}$ Maria-Rosa Ghigna, Dominique Cazals-Hatem, ${ }^{* *}$ Edmund M. Lau, ${ }^{\dagger \dagger}$ Peter Dorfmüller, ${ }^{\ddagger}$ Olivier Sitbon, ${ }^{\dagger \uparrow}$ Dominique C. Valla, ${ }^{\ddagger \delta}$ Marc Humbert, ${ }^{\dagger \oplus}$ and David Montani ${ }^{\dagger}{ }^{\dagger}$

From the Department of Respiratory Physiology, * Cochin Hospital, University Paris Descartes, Sorbonne Paris Cité, Paris, France; INSERM UMR_S 999, Pulmonary Arterial Hypertension: Physiopathology and Therapeutic Innovation, and the Department of Pathology," Marie Lannelongue Hospital, Le PlessisRobinson, France; INSERM UMR 970, ${ }^{\ddagger}$ Paris Cardiovascular Research Center, University Paris Descartes, Paris, France; the University Hospital Department of Unity, ${ }^{\S}$ Department of Hepatology, Beaujon Hospital, Hôpitaux de Paris, Clichy, France; the Department of Respiratory Medicine, ${ }^{\natural}$ University Paris-Sud, Medical School, University Paris-Saclay, Hôpitaux de Paris, National Reference Center for Severe Pulmonary Hypertension, Bicêtre Hospital, Le Kremlin Bicêtre, France; the Department of Pathology, ${ }^{* *}$ Beaujon Hospital, Hôpitaux de Paris, Clichy, France; the Department of Respiratory Medicine, ${ }^{\dagger \dagger}$ Royal Prince Alfred Hospital, Camperdown, New South Wales, Australia; and the Department of Pathology, ${ }^{\ddagger}$ University Hospital Giessen/Marburg and German Centre for Lung Research, Giessen, Germany

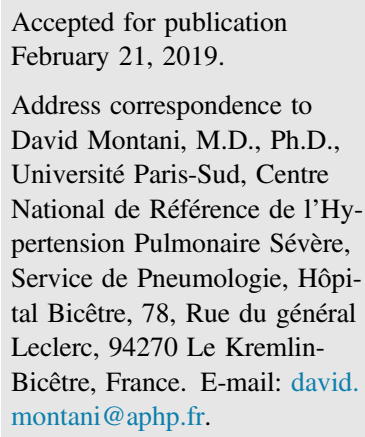

\begin{abstract}
Hepatic veno-occlusive disease (HVOD), alias sinusoidal obstruction syndrome, may develop as a complication of chemotherapy in the setting of hematopoietic stem cell transplantation. HVOD is less frequently described after exposure to chemotherapy in the nontransplant setting and can also be a complication after ingestion of toxins, such as pyrrolizidine alkaloids. Veno-occlusive disease may also affect the lungs, and it is therefore termed pulmonary veno-occlusive disease (PVOD). Similarly, PVOD can develop after exposure to chemotherapeutic agents in the treatment of solid and hematological malignancies. In addition, PVOD has also been linked to autoimmune disorders and occupational solvent exposure. Finally, the heritable form of PVOD is due to biallelic mutations of the EIF2AK4 gene. Both HVOD and PVOD share common histopathological features and pathophysiologic mechanisms. Both clinical disorders are rare complications that can appear after exposure to the common inciting trigger of chemotherapeutic agents. The present review aims to summarize the current knowledge of HVOD and PVOD and to describe both similarities as well as differences regarding both conditions. (Am J Pathol 2019, 189: 1159-1175; https://doi.org/10.1016/j.ajpath.2019.02.007)
\end{abstract}

Hepatic veno-occlusive disease (HVOD), currently termed sinusoidal obstruction syndrome in the modern nomenclature, can develop as a complication of chemotherapy in the setting of hematopoietic stem cell transplantation (HSCT). ${ }^{1}$ Although less frequently described, HVOD can occur after exposure to chemotherapy in the nontransplant setting and also after ingestion of toxins, such as pyrrolizidine alkaloids. Veno-occlusive disease can also affect the lungs and is, therefore, termed pulmonary veno-occlusive disease (PVOD). Similarly, PVOD can develop after exposure to chemotherapeutic agents in the treatment of solid and hematological malignancies. In addition, PVOD has also been linked to autoimmune disorders and occupational solvent exposure. A heritable form of PVOD can occur due to biallelic mutations of the eukaryotic translation initiation factor 2 $\alpha$ kinase 4 (EIF2AK4) gene.

\footnotetext{
Supported by Fondation du Souffle-Fonds de dotation Recherche en Santé Respiratoire (S.G.), Pulmonary Vascular Research Institute, the Eliane and Gérard French Award Foundation and the European Respiratory Society (F.P.).

S.G. and F.P. contributed equally to this work.

Disclosures: None declared.
} 
Both HVOD and PVOD are likely to share common pathophysiologic mechanisms. Both clinical disorders are rare complications that appear after exposure to the common inciting trigger of chemotherapeutic agents.

This review summarizes the current knowledge of hepatic and pulmonary veno-occlusive disease and describes similarities and differences regarding both conditions. Although HVOD is now termed sinusoidal obstruction syndrome, the term of HVOD has been used throughout this review.

\section{Hepatic Veno-Occlusive Disease or Sinusoidal Obstruction Syndrome}

\section{Historical Perspective}

Hepatic veno-occlusive disease was first recognized in South Africa in 1920 as cirrhosis resulting from ingestion of the Senecio plant, which contains the toxin pyrrolizidine alkaloid. In 1979 to 1980 , it was first demonstrated that HVOD can be a fatal complication of high-dose chemotherapy after conditioning for HSCT. ${ }^{2}$ In recent years, the term HVOD was replaced by sinusoidal obstruction syndrome because pathologic changes affect predominantly the area surrounding the hepatic central veins.

\section{Incidence and Prevalence}

An incidence rate ranging from $0 \%$ to $60 \%$ has been described for HVOD after HSCT, based on the use of different diagnostic criteria, such as the Baltimore or the Seattle criteria. The Baltimore criteria ${ }^{3}$ permit a more precise diagnosis, although the Seattle criteria ${ }^{4}$ are more widely used. Incidence data are varying because of the small sample size of some studies, variations in the conditioning regimen, and different criteria used for HVOD diagnosis.

Carreras et $\mathrm{al}^{5}$ analyzed data from 845 patients receiving allogeneic HSCTs over a period of 24 years. In this study cohort, incidence was $9 \%$ using the Baltimore criteria and $14 \%$ using the Seattle criteria. In another study, Coppell et $\mathrm{al}^{1}$ performed a meta-analysis regarding patients who developed HVOD after stem cell transplantation. This metaanalysis included 135 studies between 1979 and 2007, with 24,920 patients, of whom 3425 developed HVOD. The mean incidence rate of HVOD was $13.7 \%$ (95\% CI, $13.3 \%-14.1 \%$ ), with absolute values ranging from $0 \%$ to $62.3 \%$ in the included studies. Using the Seattle criteria, the incidence rate was $17.3 \%$ (95\% CI, 16.7\%-17.9\%; range, $0 \%$ to $62.3 \%$ ), whereas the more stringent Baltimore criteria produced an incidence rate of $9.6 \%(95 \% \mathrm{CI}, 8.8 \%-10.4 \%$; range, $0 \%$ to $28.9 \%$ ), reflecting the increased stringency of the Baltimore criteria for HVOD diagnosis. Only five studies reported an HVOD incidence of $>40 \%$, and all of these studies were enriched with high-risk patients.

Incidence data after exposure to chemotherapy in the nontransplant setting suggest a clear association between sinusoidal changes after exposure to several chemotherapeutic drugs, mostly oxaliplatin, with an incidence rate as high as $75 \%$. $^{6}$ Unfortunately, data are lacking regarding the use of a standardized diagnostic criterion for HVOD. Viganò et $\mathrm{al}^{7}$ analyzed patients who were treated with oxaliplatin- and/or irinotecan-based preoperative chemotherapy before liver resection for colorectal metastases between 1998 and 2011. A total of $38.4 \%$ of patients developed HVOD without any information regarding the criteria used for HVOD diagnosis. Incidence data regarding consumption of herbal remedies are scare, and only sporadic cases have been reported since the mid-1980s. ${ }^{6}$

\section{Onset of Symptoms}

The duration between exposure to conditioning regimen and symptom onset is typically short in the context of HSCTrelated HVOD. In general, HVOD develops during the first 30 days after conditioning therapy. ${ }^{8,9}$ Wingard et $\mathrm{al}^{10}$ reported an onset of symptoms after transplantation of 3 to 21 days (median, 18 days). The onset of symptoms after exposure to oxaliplatin-associated sinusoidal lesions in the setting of chemotherapy for liver metastasis is unclear because symptoms are often mild and the impact on patient outcome is uncertain. ${ }^{6}$ The delay of symptoms after exposure to pyrrolizidine alkaloid-containing plants is variable, varying from an acute clinical presentation with a rapid onset of symptoms to a chronic form of HVOD that is clinically indistinguishable from liver cirrhosis. ${ }^{6}$

\section{Pathogenesis}

The pathogenesis of HVOD is thought to be the result of toxic injury from the conditioning regimen after HSCT, leading to damage and activation of endothelial cells and central venous occlusion via a prothrombotic hypofibrinolytic state. ${ }^{11}$ The first toxic injury occurs to sinusoidal endothelial cells and hepatocytes in zone 3 of the liver acinus. $^{12}$

Endothelial cells are involved in the regulation of the equilibrium between prothrombotic and antithrombotic states. Injury to endothelial cells may be responsible for a disruption of the thrombo-fibrinolytic balance, as well as cytokine release from the injured tissue. ${ }^{13}$ Structurally, the damaged endothelial cells compromise the integrity of the fenestrated sinusoidal endothelium. The sinusoidal endothelial cells round up, allowing gaps in the sinusoidal barrier to develop and extravasation of blood, leukocytes, and cellular debris into the space of Disse. This is responsible for cell accumulation and deposition of fibrin causing obstruction of sinusoidal endothelial cells. ${ }^{9}$ Furthermore, endothelial cell injury leads to up-regulation of prothrombotic pathways, resulting in platelet activation, platelet and leukocyte adhesion, and fibrin-related aggregates. ${ }^{13,14}$ These events are followed by further pathologic changes of the vasculature, with thickening of the subintimal zone, and sclerosis/narrowing of the venular lumen. ${ }^{13,14}$ 


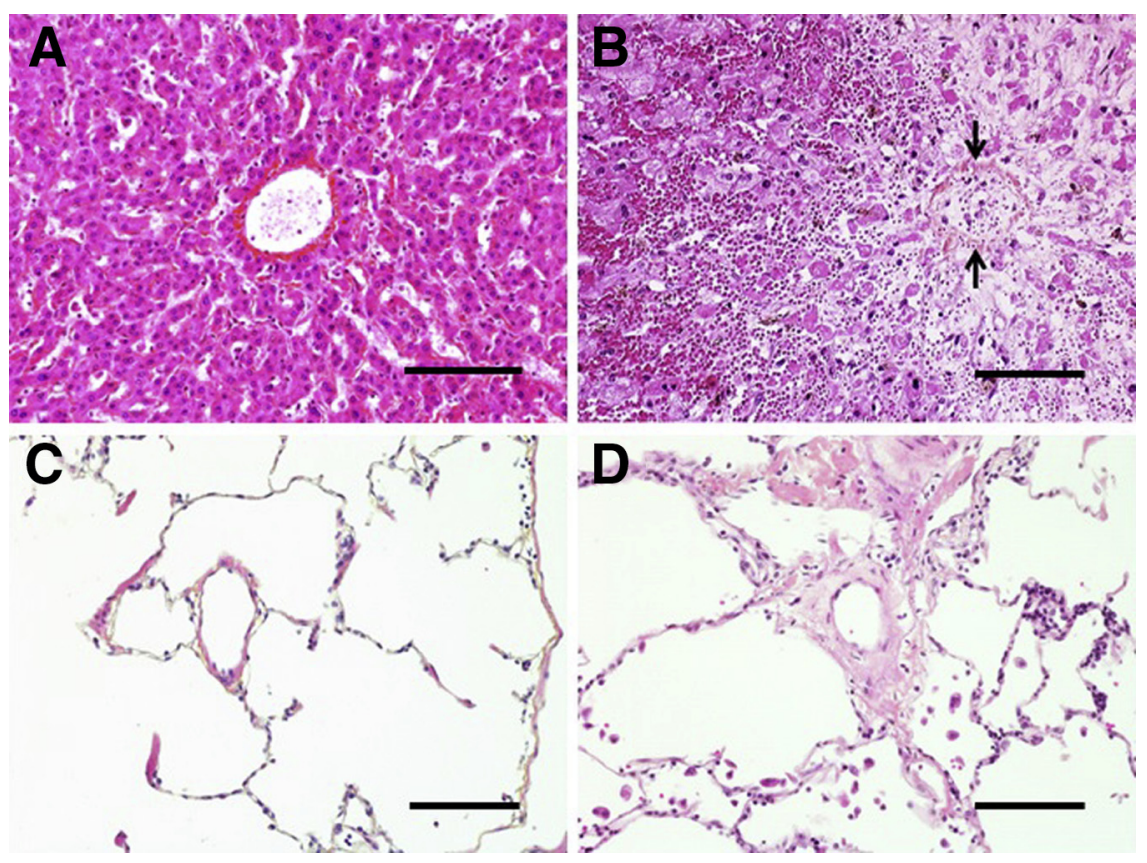

Figure 1 Vascular changes in hepatic (HVOD) and pulmonary (PVOD) veno-occlusive disease (hematein, eosin, and saffron stains). A: Normal, unremodeled central venule from a liver of a control patient, lacking any signs of hepatic disease. B: Hepatic tissue from a patient with HVOD, with a quasi-occluded central venule (between arrows) displaying loose intimal fibrosis; note the circumferential centrilobular necrosis and congestion of the sinusoids. C: A normal preseptal venule from the lungs of a patient without any signs of pulmonary disease. $\mathbf{D}$ : A remodeled venule from the lungs of a patient experiencing PVOD. The intima shows rather loose, paucicellular fibrosis and narrowing of the lumen; a mild thickening of the adjacent alveolar septa can be observed, and there are several macrophages within the alveolar space. Scale bars $=100 \mu \mathrm{m}$ (A-D). Original magnification, $\times 200($ A-D).
An animal model of HVOD using the administration of the chemotherapeutic agent FOLFOX (folinic acid, fluorouracil, and oxaliplatin) to mice has further improved the understanding of HVOD pathogenesis. ${ }^{15}$ FOLFOX-induced HVOD in mice is mainly characterized by sinusoidal dilatation and hepatocyte atrophy. However, endothelial destruction and hepatocyte necrosis are relatively inconspicuous. ${ }^{6}$ It was demonstrated that chemotherapeutic agents induced sinusoidal changes through the activation of the proinflammatory pathways involving up-regulation of vascular endothelial growth factor and IL-6. ${ }^{15}$ Therefore, it is still unclear if sinusoidal changes reported in oxaliplatinbased chemotherapy are similar to lesions observed in HSCT-related HVOD or pyrrolizidine alkaloid-induced HVOD. ${ }^{16}$

\section{Histopathological Findings}

Transjugular liver biopsy, performed in the early stages of HVOD, shows dilatation and sinusoidal engorgement and extravasation of red blood cells through the space of Disse, associated with perivenular hepatocyte necrosis. Changes in the central vein include subendothelial edema and hemorrhage in the wall of venules. ${ }^{17}$ In advanced stages of disease, complete fibrous obliteration of the central venule lumen and centrilobular sinusoidal fibrosis are observed. ${ }^{18}$ Liver abnormalities found in patients exposed to chemotherapy for liver metastasis showed sinusoidal dilatation predominating in the centrilobular area, perisinusoidal fibrosis, and centrilobular fibrosis, as well as atrophy of the liver cell plate. ${ }^{6}$ Figure 1, A and B, shows acute HVOD, characterized by centrilobular endothelial damage leading to occlusion of small hepatic veins with secondary congestion and necrosis, in comparison with a healthy control.

\section{Clinical Presentation and Diagnostic Approach}

The clinical presentation of patients experiencing HVOD after HSCT is mainly characterized by weight gain with ascites, painful hepatomegaly, and jaundice. HVOD after exposure to oxaliplatin is different and notably characterized by hepatic decompensation after surgery. HVOD diagnosis is based on the development of typical clinical signs in an at-risk patient, complemented by an increase in serum bilirubin and liver transaminases. Although biomarkers of endothelial cell injury have been identified, ${ }^{19,20}$ no specific laboratory biomarker is yet available that is both specific and sensitive for HVOD diagnosis. Imaging techniques that may be helpful include Doppler ultrasound, abdominal computed tomographic (CT) scan, magnetic resonance imaging, and $18 \mathrm{~F}-$ fluorodeoxyglucose positron emission tomography/CT.

Doppler ultrasound is used for HVOD diagnosis, but this tool has limitations. ${ }^{21}$ In the early stages of HSCT-related HVOD, Doppler ultrasound abnormalities, such as hepatomegaly, splenomegaly, gallbladder wall thickening, ascites, and portal venous flow abnormalities, are all nonspecific abnormalities. $^{21,22}$ A decrease in velocity or a reversal of the portal venous flow is considered more specific for HVOD, but this usually occurs late in the disease. ${ }^{21-23} \mathrm{An}$ abdominal CT scan might be useful in differentiating HVOD from graftversus-host disease (GvHD) based on the presence of periportal edema, ascites, and a narrow right hepatic vein. In contrast, the presence of small-bowel wall thickening suggests acute GvHD. ${ }^{24}$ Magnetic resonance imaging may show patent hepatic veins but patchy signal enhancement of the liver in more severe forms of HVOD. ${ }^{25,26}$ Metabolic imaging with $18 \mathrm{~F}$-fluorodeoxyglucose positron emission tomography/CT can be used to assess increased glucose avidity of the 
liver, and this can be used to observe therapeutic response to defibrotide. Although promising, further studies of $18 \mathrm{~F}-$ fluorodeoxyglucose positron emission tomography/CT are needed. ${ }^{27}$

Numerous novel tools show promise in facilitating the diagnosis of HVOD. In a rat model of HVOD, acoustic radiation force impulse elastography (FibroScan; Echosens, Paris, France) has been demonstrated to have utility in diagnosis, assessment of severity, and disease follow-up. ${ }^{28}$ Liver shear-wave velocity is elevated in HVOD in proportion to the degree of sinusoidal injury and lobular inflammation in the rat model of HVOD. It has been reported that transient elastography, a noninvasive and reproducible method for the assessment of hepatic fibrosis in chronic liver disease, is feasible by measuring liver stiffness. ${ }^{29}$ Transient elastography is a rapid and easy technique to identify patients at risk for developing liver complications after HSCT, even if further studies are needed. ${ }^{29}$

Liver biopsy remains the gold standard for HVOD diagnosis. ${ }^{30,31}$ A transjugular route is required in most patients because of bleeding risk (thrombocytopenia and coagulopathy) and/or abdominal ascites. Hepatic venous pressure gradient, measured at the time of transjugular liver biopsy, is commonly $>10 \mathrm{mmHg}$ in patients with HVOD compared with those with other liver conditions in the HSCT setting. However, the diagnostic performance of hepatic venous pressure gradient measurement is not sufficient to exclude the need to perform a transjugular liver biopsy for definitive diagnosis. Recent reports on the safety of transjugular liver biopsy in HSCT patients support its role in the diagnosis of HVOD. ${ }^{32,33}$

\section{Differential Diagnosis}

Several conditions can mimic HVOD and must be excluded before a diagnosis of HVOD can be made. These include liver toxicity without HVOD, viral or fungal hepatitis, severe sepsis, acute liver GvHD, liver tumor infiltration, and cardiac complications, including constrictive pericarditis, right-sided heart failure, or thrombotic endocarditis. ${ }^{34,35}$

\section{Genetics}

Genetic abnormalities associated with HVOD development have been described. Busulfan (a usual component of the conditioning regimen for HSCT) and the metabolites of cyclophosphamide are conjugated with glutathione by enzymes of the glutathione S-transferase family. It has been reported that the glutathione S-transferase M1-null genotype predisposes patients undergoing HSCT to HVOD. ${ }^{36}$

The liver is a major site of iron deposition in hereditary hemochromatosis (HFE-associated hemochromatosis), and iron has oxidative toxicity. It has been hypothesized that the genotype of the hereditary hemochromatosis gene ( $H F E$ ) might influence the risk of HVOD development after myeloablative HSCT. Furthermore, a common variant of the ratelimiting urea cycle enzyme, carbamyl-phosphate, can modify the effect of the hereditary hemochromatosis genotype. It has been shown that the risk of HVOD is significantly increased in carriers of the $\mathrm{C} 282 \mathrm{Y}$ mutation of the HFE gene, with the highest level seen in those with homozygosity for the C282Y mutation. The carbamyl-phosphate synthetase allele A, which encodes a more efficient urea cycle enzyme, reduces the risk of HVOD in those with a mutation in the HFE gene. Therefore, $\mathrm{C} 282 \mathrm{Y}$ mutations of the $H F E$ gene are a risk factor for HVOD. Knowledge of these genotypes and monitoring of iron stores may potentially facilitate risk stratification in patients at risk of HVOD and also test novel strategies to prevent HVOD, such as iron chelation and pharmacologic support of the urea cycle. ${ }^{37}$

A familial form of HVOD in patients presenting with an underlying immunodeficiency was first described 40 years ago. ${ }^{38}$ Familial HVOD with immunodeficiency, a rare form of severe combined immune deficiency, was first identified in Australian-Lebanese families because of homozygous mutations in SP110, a gene encoding a promyelocytic leukemia protein nuclear body-associated protein. ${ }^{39}$ Mutations in the SP110 gene result in infantile onset of HVOD with immunodeficiency because of decreased SP110 protein levels and impaired late B-cell differentiation. Later on, it was demonstrated that a range of mutations in SP110 caused diminished SP110 protein levels and HVOD with immunodeficiency, and this was not restricted to the Lebanese population. ${ }^{40}$ HVOD with immunodeficiency frequency has been estimated at 1:2500 live births in the Sydney Lebanese population, with 19 cases identified over a period of 30 years. ${ }^{41}$ In conclusion, mutations and polymorphisms in genes involved in hepatic metabolism and immune regulation can predispose to HVOD development.

Table 1 Clinical Criteria for HVOD Diagnosis

\begin{tabular}{lc}
\hline Baltimore criteria $^{3}$ & Modified Seattle criteria $^{4}$ \\
\hline $\begin{array}{l}\text { Clinical features of HVOD before day } 20 \text { after HSCT, } \\
\text { bilirubin } \geq 2 \mathrm{mg} / \mathrm{dL} \text { before day } 21 \text { after HSCT, and at }\end{array}$ & Presence before day 30 after HSCT of two or more of the following: \\
least two of the following clinical parameters: & Bilirubin $\geq 2 \mathrm{mg} / \mathrm{dL}$ \\
Ascites & Hepatomegaly, right upper quadrant pain \\
Weight gain $>5 \%$ over baseline & Ascites, with or without unexplained weight gain of $>2 \%$ over baseline \\
Hepatomegaly (usually painful) & \\
\hline
\end{tabular}

HVOD, hepatic veno-occlusive disease; HSCT, stem cell transplantation. 
Table 2 Chemotherapeutic Agents Identified in the Literature, Favoring HVOD and PVOD

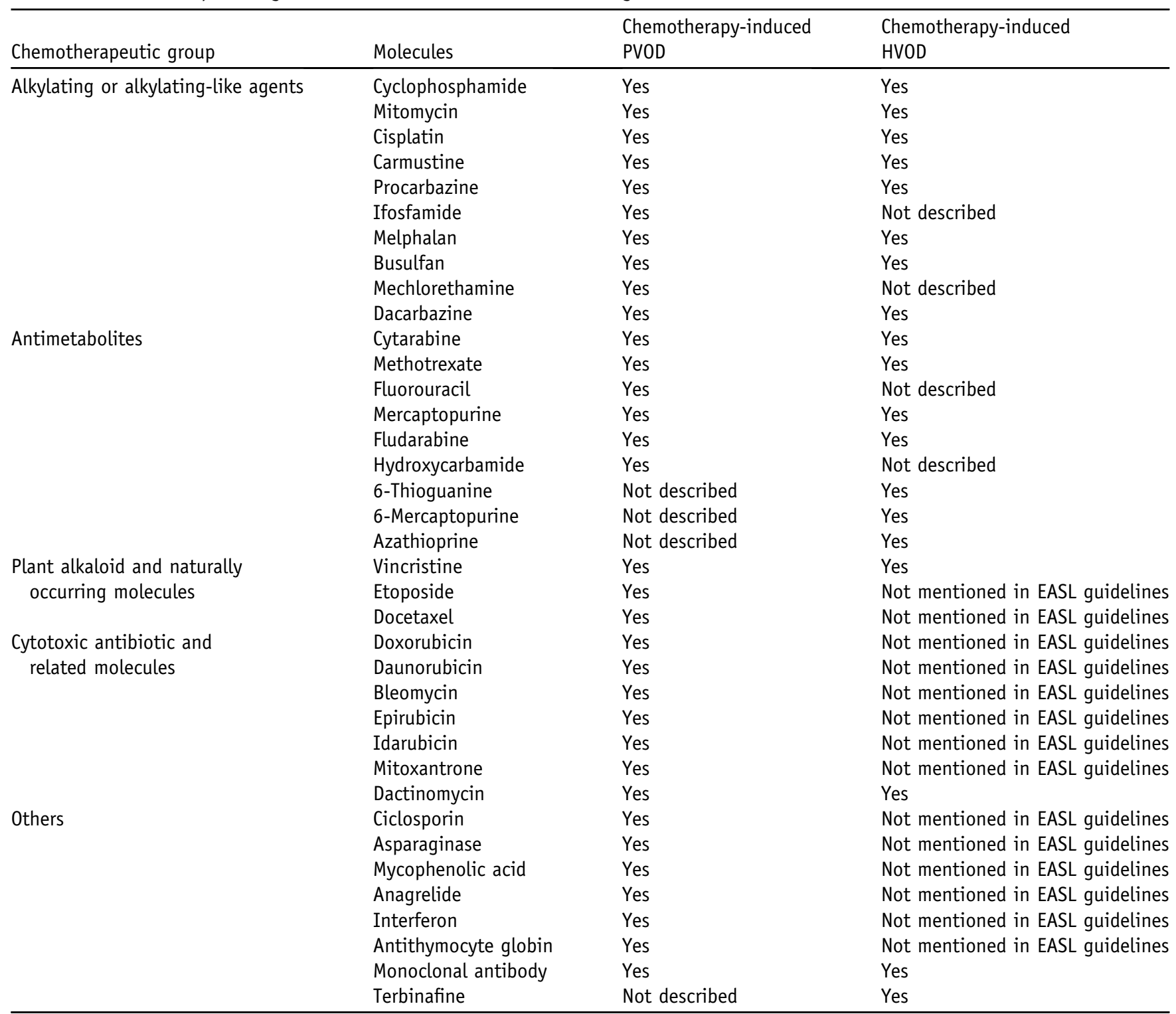

HVOD is also described in the setting of traditional herbal remedies, after bone marrow transplant, after total body or hepatic irradiation, and after platelet transfusion containing ABO-incompatible plasma. Molecules were identified in the EASL guidelines and in a literature review from Ranchoux et al. ${ }^{45}$

EASL, European Association for the Study of the Liver; HVOD, hepatic veno-occlusive disease; PVOD, pulmonary veno-occlusive disease.

\section{Classification System and Diagnostic Criteria}

To ascertain disease severity and evaluate the outcome of HVOD patients, a classification system was established, distinguishing mild, moderate, and severe forms of HVOD. ${ }^{42}$ Mild disease is characterized by a self-limiting course, and most cases resolve without medical therapy. Moderate disease shows evidence of liver injury and fluid retention and should be managed medically with diuretics and analgesic therapy, if required. In both cases, full recovery is also expected to occur. Severe disease can lead to multiorgan failure, ${ }^{43}$ and intensive care unit therapy is frequently needed. Diagnostic criteria were established by the Baltimore and the Seattle working groups (Table 1). The Baltimore criteria ${ }^{3}$ permit a more precise diagnosis, although the Seattle criteria are more widely used. ${ }^{4}$ Recently, the European Society for Blood and Marrow Transplantation has suggested the addition of hemodynamic and/or ultrasound evidence to improve the diagnostic accuracy of HVOD. ${ }^{44}$

\section{Etiology and Risk Factors}

Chemotherapeutic agents associated with HVOD and PVOD development are detailed in Table 2. Molecules were identified in the European Association for the Study of the Liver guidelines and in a literature review. ${ }^{45}$

Development of HVOD has been reported to be associated with exposure to three main groups of drugs/toxins: i) 
pyrrolizidine alkaloids; ii) chemotherapy agents, such as oxaliplatin or irinotecan, used for liver metastasis in colorectal malignancy; and iii) a conditioning regimen for HSCT. In HSCT, the major risk factors for HVOD include a highintensity conditioning regimen, allogeneic transplantation, and exposure to exogenous estrogens or progesterone in women; previous myeloablative chemotherapy; and preexisting liver disease.

HVOD, after exposure to pyrrolizidine alkaloids in the 1950s, was associated with the consumption of bush tea. ${ }^{6}$ Nowadays, HVOD development after exposure to pyrrolizidine alkaloid is scarce and is reported after consuming plants that contain pyrrolizidine alkaloid. ${ }^{46}$ Sinusoidal injury may occur after chemotherapy treatment for colorectal malignancy after exposure to oxaliplatin, irinotecan, or 5-fluorouracile.

\section{Prevention Strategies}

Pharmacologic HVOD prophylaxis has been extensively studied, but only ursodeoxycholic acid (UDCA) has evidence to support its clinical efficacy and should, therefore, be considered to prevent HSCT-associated HVOD, according to current guidelines. ${ }^{47}$

Ruutu et $\mathrm{al}^{48}$ reported the long-term results of a prospective randomized study on the use of UDCA to prevent hepatic complications after allogeneic HSCT. A total of 242 patients were randomized to receive UDCA from the beginning of the conditioning until 90 days after transplantation. UDCA administration reduced significantly the proportion of patients developing high serum bilirubin levels as well as the incidence of severe GvHD, liver GvHD, and intestinal GvHD. In the UDCA prophylaxis group, relapse-free mortality was lower and overall survival was better than in controls. In accordance with these observations, UDCA administration reduced hepatic abnormalities and severe acute GvHD and improved survival. These results suggest a role for UDCA in the prevention strategy of transplant-related complications in allogeneic transplantation. ${ }^{49}$

Another randomized controlled trial tested the prophylactic use of defibrotide, a single-stranded polydeoxyribonucleotide acting as an adenosine receptor agonist. ${ }^{44}$ Pediatric patients undergoing HSCT were randomized to defibrotide $(n=180)$ versus placebo $(n=176)$, and they were followed up for a median of 180 days after transplantation. Thirty days after HSCT, $12 \%$ in the defibrotide group developed HVOD compared with $20 \%$ in the control group (risk difference, $-7.7 \% ; 95 \% \mathrm{CI},-15.3 \%$ to $-0.1 \% ; Z$ test for competing risk analysis $P=0.0488$ ). However, no differences were observed regarding mortality due to HVOD at 100 days after HSCT ( $2 \%$ in the defibrotide group versus $6 \%$ in the control group; $P=0.10) .{ }^{44}$ The prophylactic use of defibrotide in adults is still debated in the literature (see below). Other agents, such as pentoxifylline, unfractionated heparin, low-molecular-weight heparin, and antithrombin, have been tested in HVOD prophylaxis and are not recommended because of the lack of efficacy. ${ }^{47}$

\section{Treatment}

The therapeutic armamentarium is small regarding patients with established HVOD. ${ }^{34}$ In line with recently updated guidelines, medical options to treat HVOD are limited to defibrotide and methylprednisolone. ${ }^{47}$

Richardson et $\mathrm{al}^{50}$ performed a phase 3 trial evaluating the safety and efficacy of defibrotide in patients with severe $\operatorname{HVOD}(n=102)$ associated with multiorgan failure. Patients receiving defibrotide were compared with historical controls $(n=32)$ using a propensity-adjusted analysis. The primary end point was survival at day 100 plus after HSCT, with observed rates of $38.2 \%$ in the defibrotide group and $25 \%$ in the control group (23\% estimated risk reduction; $95.1 \% \mathrm{CI}$, 5.2-40.8; $P=0.0109$ ). Observed day 100-plus complete response rates equaled $25.5 \%$ for defibrotide and $12.5 \%$ for controls (19\% difference using a similar method; $95.1 \% \mathrm{CI}$, $3.5-34.6 ; P=0.0160)$. It was concluded that the use of defibrotide in patients experiencing severe HVOD was associated with significant improvement in day 100-plus survival and complete response rate. ${ }^{50}$ In July 2004, the European Medicines Agency granted defibrotide an orphan drug status for prophylaxis and curative treatment (as per manufacturer's instructions/recommendations). However, the European commission gave a negative opinion in March 2013 on the use of defibrotide in HVOD prophylaxis because of the lack of high-quality clinical evidence and the weak method of the unique randomized multicenter European study in pediatric populations. ${ }^{44}$ In addition, French authorities considered that defibrotide represented only a minor improvement in the therapeutic strategy of severe HVOD because of its high cost and the absence of high-quality data from randomized controlled trials.

Short-term high-dose methylprednisolone $(0.5 \mathrm{mg} / \mathrm{kg}$ per dose intravenously every 12 hours for 14 doses) was evaluated in an observation study of 48 patients diagnosed with HVOD after HSCT. ${ }^{51}$ Thirty patients (63\%) responded with a reduction in total serum bilirubin of $\geq 50 \%$ after 10 days of treatment. Of the 30 responders, 25 survived up to day 100 plus, whereas all but three nonresponders died within 100 days after HSCT, with a probability of survival of 58\% among responders and $10 \%$ among nonresponders. Prospective comparative studies are needed to confirm these results. ${ }^{51}$ Finally, supportive care plays a key role in the management of patients with HVOD. Careful fluid management can be challenging to maintain intravascular volume and renal perfusion, despite fluid retention and ascites. ${ }^{47}$

\section{Outcome}

Most cases of mild-moderate HVOD resolve spontaneously, ${ }^{34}$ with 100 -day mortality of up to $80 \%$ in severe HVOD due to multiorgan failure. ${ }^{1}$ The mortality rate has 
declined since 1997 because of better screening methods of underlying liver diseases before conditioning therapy for HSCT and after introduction of the reduced-intensity conditioning for allogeneic HSCT. In addition, risk factors for HVOD development are now better identified, and supportive management for severe HVOD has improved. ${ }^{1,52}$

\section{Animal Models}

Because of the scarcity of HVOD, animal models are lacking and the understanding of this entity is mainly based on clinical observations. DeLeve et $\mathrm{al}^{53}$ established a reproducible monocrotaline (MCT) rat model in 1999, which contributed to a better understanding of underlying mechanisms responsible for HVOD development. Two mechanisms are believed to play a key role in HVOD, represented by an initial injury to sinusoidal endothelial cells and toxic injury to bone marrow progenitors, preventing the replacement of injured endothelial cells. Coagulative necrosis follows sinusoidal injury and resolves with improvement in sinusoidal endothelial cell morphology. Moderate-to-severe central vein fibrosis occurs after reappearance of sinusoidal-lining cells and resolution of hepatocyte necrosis. The inflammatory response within the lobule and central veins is a result of recruitment of monocytes, whereas Kupffer cells are decreased in number. ${ }^{53}$ Several years ago, Robinson et $\mathrm{al}^{15}$ aimed to establish a rodent model to investigate underlying mechanisms of FOLFOX-induced HVOD. This HVOD model showed that the use of antioxidants alongside oxaliplatin-based chemotherapy may be of value in preventing HVOD development in patients with colorectal liver metastases. ${ }^{15}$ Czauderna et $\mathrm{al}^{54}$ showed, in 2000, that dactinomycin caused liver lesions similar to HVOD after histopathological examinations of exposed rats. Histopathological changes of HVOD became more and more intense after consecutive cycles of dactinomycin. Lesions of the central veins and liver sinusoidal endothelium predominated. Treatment with amifostine before dactinomycin exposure attenuated the pathomorphologic changes in the liver. ${ }^{54}$

\section{Pulmonary Veno-Occlusive Disease}

\section{History}

The current classification system of pulmonary hypertension $(\mathrm{PH})$ distinguishes $\mathrm{PH}$ into groups that share similar pathophysiology, hemodynamic characteristics, and treatment approaches. Five groups of disorders that cause $\mathrm{PH}$ are identified as pulmonary arterial hypertension (PAH; group 1), pulmonary hypertension due to left-sided heart disease (group 2), pulmonary hypertension due to chronic lung disease and/or hypoxia (group 3), chronic thromboembolic pulmonary hypertension (group 4), and pulmonary hypertension due to unclear and/or multifactorial mechanisms (group 5). According to recently updated guidelines, PVOD is referred to group $1 \mathrm{PAH}$ because of evidence suggesting a continuum between arterial, capillary, and vein involvement in $\mathrm{PAH}^{55}$

The remodeling of the pulmonary venules is one of the main characteristics of PVOD. Although PAH and PVOD share similar clinical and hemodynamic presentations, both entities should be distinguished because of the worse PVOD prognosis and the possible occurrence of life-threatening pulmonary edema after PAH-specific therapy initiation in PVOD patients.

The first documented case of PVOD in the literature was described by Hora in $1934 .{ }^{56}$ Some years later, Heath et $\mathrm{al}^{57}$ coined the term of pulmonary veno-occlusive disease in 1966 after the histologic analysis of a 45-year-old woman with clinical features suggestive of primary PH (now termed idiopathic pulmonary arterial hypertension), showing diffuse and massive involvement of venules and septal veins in a vasculopathy characterized by intimal fibrosis and smooth muscle cell hyperplasia. These distinctive lesions appeared to constitute a separate disease entity, for which the name pulmonary veno-occlusive disease was introduced. In 2013, two teams demonstrated that heritable PVOD and heritable pulmonary capillary hemangiomatosis were due to biallelic mutations in the EIF2AK4 gene. ${ }^{58,59}$

\section{Incidence and Prevalence}

PVOD is a rare disorder, with an estimated annual incidence rate of 0.1 to 0.2 per million. ${ }^{60}$ The reported incidence rate is probably underestimated because of misclassification of patients, with PVOD being mislabeled as PAH. In addition, the incidence rate is likely to be much higher in patients with a predisposing risk factor, such as autoimmune disorders (most notably, systemic sclerosis); occupational exposure to organic solvents; and treatment with alkylating agents, like mitomycin (MMC), in the setting of cancer. The incidence rate of PVOD in patients exposed to MMC therapy, who have anal cancer, has been estimated to be approximately 3.9 per 1000 patients. ${ }^{61}$ Although a link between PVOD and occupational solvent exposure has been found, there are no epidemiologic data to allow an estimation of risk in workers exposed to chemical solvents.

\section{Onset of Symptoms and Sex Predominance}

Administration of MMC for anal cancer in humans may trigger PVOD development. ${ }^{61}$ The delay between the last cycle of chemotherapy with MMC and PVOD diagnosis was 4 months (range, 2 to 12 months). Patients were mainly females $(86 \%)$. However, no sex predominance was observed regarding patients identified in the Pulmonary Hypertension Network with chemotherapy-induced PVOD and after review of the literature. ${ }^{45}$ In the literature review, cyclophosphamide was the most common inciting agent in chemotherapyassociated PVOD, but these data should be interpreted with caution because cyclophosphamide was administered with 
various other chemotherapeutic products in the setting of different malignancies. A different chemotherapy regimen and individual susceptibility may also explain the various delays between administration of chemotherapeutic agents and onset of symptoms. For example, the cardiovascular toxicity of chemotherapy drugs depends on the cumulative dose, the intensity of dosing, the patient's age, concurrent administration of other cardiotoxic agents, and history of preexisting cardiovascular disorders. ${ }^{62}$ In the case of aggressive chemotherapeutic regimens, the delay between administration and onset of symptoms is probably short. In the case of chronic occupational solvent exposure, the delay is presumably longer because of repeated low-grade injury without any immediate manifestation of clinical symptoms. In the French study, the mean delay between PVOD diagnosis and exposure was 48 years. The fact that males were mainly affected by solvent exposure-induced PVOD is probably a societal effect, ${ }^{63}$ rather than an underlying sex susceptibility, but this hypothesis remains speculative. Idiopathic PAH and PVOD are pathologies that are female predominant. ${ }^{64}$ In the context of heritable PAH due to a BMPR2 mutation, the female/male ratio of PAH has recently been estimated to be $3: 1$, with the female penetrance being approximately $42 \%$ and the male penetrance being only approximately $14 \% .{ }^{65}$ However, as far as we know, this female predisposition to develop PAH is not encountered in all animal models of PAH. Conversely, there is a more aggressive course of monocrotaline-induced pulmonary hypertension in males compared with females. In a recent study, MCT exposure (one of the widely used animal models for $\mathrm{PH}$ ) induced right ventricular hypertrophy only in male rats. The hearts of MCT-treated female rats did not exhibit right ventricular hypertrophy within a 5-week interval. ${ }^{66}$ In contrast to these observations, MMC-induced PVOD is clearly female predominant, and this observation was confirmed in our animal model. ${ }^{61}$

\section{Pathogenesis}

In PVOD, vascular lesions are encountered in all three compartments of the pulmonary vasculature (veins, capillaries, and arteries). ${ }^{60}$ Inflammation and dysregulated immunity are implicated in the pathogenesis of PVOD, as supported by animal models ${ }^{45}$ and human data. ${ }^{67}$ PVOD and PAH share some common features regarding the pathogenesis, such as activation of the platelet-derived growth factor pathway and serotonin-induced smooth muscle hyperplasia. ${ }^{68}$ In PVOD, endothelial nitric oxide synthase activity is specifically reduced when remodeling of pulmonary arteries is concomitantly present. ${ }^{69}$ Inflammatory conditions are associated with PVOD development, and immune-mediated injury of pulmonary venules has been suggested to be a potential mechanism. Cytotoxic T-cell, natural killer cell, and natural killer T-cell functions probably play a critical role in the vascular remodeling in PVOD. Analysis of the cytolytic compartment of inflammatory cells showed significant modifications in the proportions of circulating cytotoxic T-cell, natural killer cell, and natural killer T-cell populations in PVOD. ${ }^{67}$

A genetic basis of PVOD, caused by biallelic mutations of the EIF2AK4 gene, was recently described. ${ }^{58}$ The EIF2AK4 gene codes for general control of nondepressible 2 (GCN2). GCN2 belongs to a family of kinases that phosphorylate the $\alpha$ subunit of eukaryotic translation initiation factor 2. GCN2 is up-regulated during the integrated stress response, which is activated by viral infection, hypoxia, and amino acid starvation. The role and expression of GCN2 in the pulmonary vasculature are largely unknown, although it is likely that a reduction of GCN2 activity due to loss-of-function EIF2AK4 mutations may lead to increased inflammation, oxidative stress, and vulnerability.

Although little remains known regarding the GCN2 function in the pulmonary vasculature, it is clear that GCN2 dysfunction is a central mechanism in PVOD pathogenesis. Moreover, reduced GCN2 expression in the lung vasculature has been shown in experimental models and human PVOD. ${ }^{61}$ Interesting, GCN2 dysfunction may be also involved in $\mathrm{PAH}$ pathogenesis, ${ }^{70}$ highlighting its key role in pulmonary vascular remodeling.

\section{Histopathological Findings}

The histologic hallmark of PVOD is the diffuse involvement of venules and septal veins in a vasculopathy characterized by smooth muscle cell hyperplasia and intimal fibrosis, resulting in luminal narrowing or obliteration of affected vessels (Figure 1, C and D) ${ }^{60,71}$ Intimal remodeling of veins and venules may range from loose fibrous tissue with variable cellularity to dense, paucicellular sclerotic lesions. Incrustations of iron or calcium residues can be found in the vessel walls, and giant cell foreign body-type granulomas may be observed, although this finding is not frequent. Another important aspect of vascular remodeling in PVOD is the focal multiplication of capillaries within the alveolar septa: there are multiple layers of capillaries, frequently associated with mild interstitial inflammatory infiltrates. At low-microscopic magnification, these capillary hemangiomatosis-like foci are distributed in a patchy pattern throughout the lung and correspond to the typical centrilobular ground-glass opacities observed on high-resolution $\mathrm{CT}$ of the chest. These hemangiomatosis-like foci are virtually always accompanied by microvessels (arterioles or venules) that show intense smooth muscle cell hyperplasia. Hence, both compartments, capillaries and microvessels, appear to display a reactive state (capillary multiplication and smooth muscle cell hyperplasia of microvessels), which until now has been explained as a secondary reaction to capillary and precapillary pressure increase due to the obstruction on the post-capillary level. ${ }^{72}$ However, recent quantitative morphometric data from our institution have shown that substantial constrictive remodeling of pulmonary muscular-type arteries (between 70 and $300 \mu \mathrm{m}$ in diameter) is virtually always present in PVOD. ${ }^{70}$ In this new light, the clear-cut discrimination between a primary 


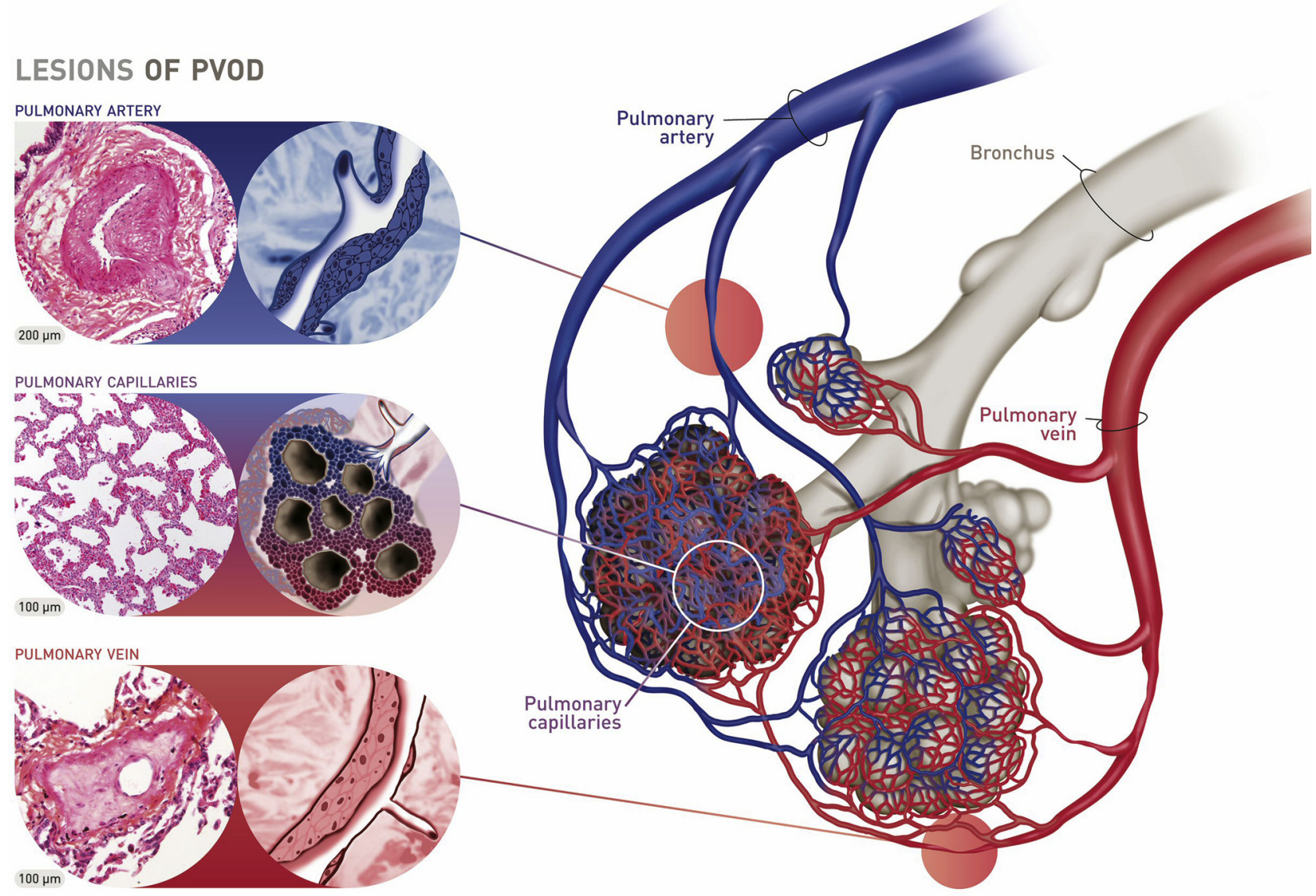

Figure 2 Vascular lesions and pathologic features of pulmonary veno-occlusive disease (PVOD). All three compartments of the pulmonary microcirculation are affected in PVOD, although there is preferential involvement of the pulmonary venous system. Venular lesions include intimal fibrosis of small preseptal venules. Capillary lesions are characterized by exuberant proliferation of endothelial cells (capillary hemangiomatosis). Arterial lesions resemble those of pulmonary arterial hypertension with intimal fibrosis and medial hypertrophy, but complex plexiform lesions are absent. Reproduced with permission of the (c) ERS 2018: European Respiratory Journal May 2016, 47 (5) 1518-1534; D0I: 10.1183/13993003.00026-2016. ${ }^{60}$

pulmonary venous and a primary pulmonary arterial disease (PVOD versus PAH) appears questionable. Nonetheless, morphologic differences still persist, and the so-called plexiform lesions found in PAH are virtually never observed in patients with clinical and histologically confirmed PVOD (Figure 2).

\section{Clinical Presentation and Diagnostic Approach}

Clinical presentation is characterized by an insidious onset of nonspecific symptoms, like shortness of breath and general signs of $\mathrm{PH}$, including lower limb edema. Clinical signs typically encountered in the setting of PVOD are right ventricular heave, loud pulmonary component of second heart sound, and systolic murmur of tricuspid regurgitation, together with signs of overt right-sided heart failure in decompensated disease. ${ }^{60}$ However, no pathognomonic clinical sign for PVOD is described.

PVOD patients are typically diagnosed in advanced stages when important pulmonary hypertension has developed and, therefore, surgical lung biopsy is not recommended for diagnosis. ${ }^{60}$ A noninvasive approach is, therefore, undertaken on the basis of functional, radiological, and hemodynamic findings. Functional impairment is characterized by low diffusion capacity for carbon monoxide and hypoxemia in room air. ${ }^{73,74}$ Radiological abnormalities include groundglass opacities, septal lines, and mediastinal lymph node enlargement on chest high-resolution $\mathrm{CT} .{ }^{75}$ Hemodynamic findings consists of precapillary $\mathrm{PH}$ (mean pulmonary arterial pressure $\geq 20 \mathrm{mmHg}$, pulmonary artery wedge pressure $\leq 15$ $\mathrm{mmHg}$, and pulmonary vascular resistance $>3$ Wood units), measured by right-sided heart catheterization. If performed, bronchoalveolar lavage may reveal occult alveolar hemorrhage with hemosiderin-laden macrophages. However, bronchoscopy is not commonly performed because of severe hypoxemia. $^{76}$

\section{Differential Diagnosis}

Differential diagnosis should include interstitial lung disease, sarcoidosis, pulmonary edema associated with leftsided heart disease, or misclassification of patients 
Table 3 Overview Regarding Similarities and Differences of HVOD and PVOD

\begin{tabular}{|c|c|c|}
\hline Variable & HVOD & PVOD \\
\hline $\begin{array}{l}\text { Incidence/prevalence } \\
\text { data }\end{array}$ & $\begin{array}{l}\text { Difficult to estimate because of small sample size } \\
\text { studies and different diagnostic criteria (Baltimore } \\
\text { or Seattle criteria) } \\
\text { Depending also on the underlying etiology of HVOD } \\
\text { Analysis of } 135 \text { studies between } 1979 \text { and } 2007 \text { with } \\
24,920 \text { patients, of whom } 3425 \text { developed HVOD, } \\
\text { reported the mean incidence of HVOD was } 13.7 \% \text {. } \\
\text { This incidence was higher using the Seattle criteria }\end{array}$ & $\begin{array}{l}\text { The estimated annual incidence rate is } 0.1 \text { to } 0.2 \\
\text { per million, but these data may be } \\
\text { underestimated because of misclassification of } \\
\text { PVOD as PAH. } \\
\text { The incidence rate of PVOD in patients exposed to } \\
\text { mitomycin and experiencing anal cancer is } \\
\text { estimated to be } 3.9 \text { of } 1000 \text { patients. }\end{array}$ \\
\hline
\end{tabular}

Onset of symptoms

Etiology and risk factors

Genetics

Clinical presentation

Diagnosis

Classification system

Prevention strategies

Histologic findings
This incidence was higher using the Seattle criteria $(17.3 \%)$ compared with the Baltimore criteria $(9.6 \%)$.

Short delay between onset of symptoms and diagnosis (3-21 days) after bone marrow transplantation

Three main causes for HVOD development are identified as follows: conditioning for HSCT, oxaliplatin-induced SOS (HVOD/SOS) in the setting of colorectal cancer, and liver disease related to pyrrolizidine alkaloids.

Genetic abnormalities are as follows: SP110 gene mutations, which result in hepatic veno-occlusive disease with immunodeficiency; GSTM-null genotype, which predisposes to HVOD in HSCT; and HFE C282Y, which is a risk factor for HVOD development.

Mainly characterized by weight gain and painful abdominal ascites after bone marrow transplantation

Different diagnostic criteria using the Baltimore or Seattle criteria, based on clinical presentation, and blood tests or criteria from the European Society for Blood and Marrow Transplantation, including imaging techniques (Doppler ultrasound or abdominal CT scan)

Liver biopsy is a safe and useful tool to diagnose HVOD.

A classification system was established, distinguishing mild, moderate, and severe HVOD.

Several performed trials, but only ursodeoxycholic acid proved efficacy to prevent HVOD

The prophylactic use of defibrotide is still debated.

Histologic characteristics include the following: in early stages, dilatation and sinusoidal engorgement and extravasation of red blood cells through the space of Disse, associated with perivenular hepatocyte necrosis; and in advanced stages, complete fibrous obliteration of the central venule lumina and centrilobular sinusoidal fibrosis.
In the setting of chemotherapy-induced PVOD, the delay between chemotherapy initiation and diagnosis of PVOD was 4 months (range, 2 to 12 months).

Different causes, mainly favoring PVOD development, are as follows: underlying autoimmune disorders, like systemic sclerosis; occupational exposures, including trichloroethylene, degreasing agents, paints, and varnish/glue; and exposure to toxic agents, including alkylating agents (mitomycin).

Genetic abnormalities are described, with the biallellic mutations of the EIF2AK4 gene responsible for heritable PVOD.

Characterized by an insidious onset of nonspecific symptoms, including fatigue and breathlessness, leading to right-sided heart failure in end-stage disease

Based on a noninvasive approach, including clinical, functional, hemodynamic, and radiological findings

Lung biopsy is not recommended to diagnose PVOD.

No established classification system

No established prevention strategy

Exposure to organic agents should be avoided, and patients treated by MMC should be monitored regularly.

Amifostine showed encouraging results for preventing PVOD in animal models.

Diffuse and massive involvement of venules and septal veins in a vasculopathy characterized by intimal fibrosis and smooth muscle cell hyperplasia, resulting in luminal narrowing or obliteration of affected vessels

Intimal remodeling of veins and venules may range from loose fibrous tissue with variable cellularity to dense, paucicellular sclerotic lesions. 
Table 3 (continued)

\begin{tabular}{|c|c|c|}
\hline Variable & HVOD & PVOD \\
\hline Treatment & $\begin{array}{l}\text { Most cases resolved spontaneously }(80 \%) \text {. } \\
\text { Medical therapy, including defibrotide and } \\
\text { methylprednisolone, is reserved to patients } \\
\text { presenting with severe HVOD. }\end{array}$ & $\begin{array}{l}\text { Medical treatment options are limited and, in most } \\
\text { cases, only symptomatic treatment options are } \\
\text { proposed. } \\
\text { Cautious off-label use of PAH therapies could be } \\
\text { discussed. } \\
\text { Lung transplantation is reserved only to highly } \\
\text { selected patients. }\end{array}$ \\
\hline
\end{tabular}

CT, computed tomography; EIF2AK4, eukaryotic translation initiation factor $2 \alpha$ kinase 4; GSTM, glutathione S-transferase; HFE, hereditary hemochromatosis; HSCT, hematopoietic stem cell transplantation; HVOD, hepatic veno-occlusive disease; MMC, mitomycin; PAH, pulmonary arterial hypertension; PVOD, pulmonary veno-occlusive disease; SOS, sinusoidal obstruction syndrome.

diagnosed as having PAH (group 1). ${ }^{77}$ Chest highresolution CT and biopsy of the lungs, depending on suspected underlying disease, may help to differentiate between these pathologies.

\section{Genetics}

The finding of the same biallelic mutations in the EIF2AK4 gene for both PVOD and pulmonary capillary haemangiomatosis $(\mathrm{PCH})$ supports that $\mathrm{PVOD}$ and $\mathrm{PCH}$ are varied manifestations of the same disease. Heritable PVOD/PCH segregates as an autosomal recessive trait with probable complete disease penetrance.

To date, EIF2AK4 biallelic mutations have been identified in $100 \%$ of the familial form of the disease but also in 9\% of PVOD patients diagnosed with an apparently sporadic disease form without a family history. ${ }^{78}$

A recent study from the French PH Network reported the genotype-phenotype correlation of 94 PVOD patients who had undergone EIF2AK4 mutation analysis. Heritable PVOD, due to EIF2AK4 mutations, presented at a younger age compared with mutation noncarriers $(25.7 \pm 10.0$ versus $58.4 \pm 15.5$ years; $P<0.0001$ ), and heritable PVOD could appear as early as birth. ${ }^{74}$ Both EIF2AK4 mutation carriers and noncarriers presented at diagnosis with severe and similar hemodynamic characteristics. Interestingly, the presence of a risk factor for PVOD (occupational exposure to organic solvents or chemotherapy) was commonly found in noncarriers but entirely absent in mutation carriers.

\section{Etiology and Risk Factors}

Several risk factors for PVOD development have been identified. Autoimmune disorders (most commonly, systemic sclerosis) are considered to be a risk factor for PVOD development. ${ }^{79,80}$ The association of occupational solvent exposures (eg, trichloroethylene, paints, and degreasing agents) and PVOD development was recently described. ${ }^{63}$ Occupational exposure to organic solvents was significantly associated with
PVOD development (adjusted odds ratio, 12.8; 95\% CI, 2.7-60.8), with trichloroethylene being the main implicated agent (adjusted odds ratio, 8.2; 95\% CI, 1.4-49.4). The median exposure duration was 17 years, and the median latency from trichloroethylene exposure to PVOD diagnosis was 48 years. Exposure to solvents occurred in mechanics, metal workers, building painters, and cleaners. ${ }^{63}$ In this study, the association between smoking and PVOD was confirmed. This association seems to be sex independent. ${ }^{63}$ It was already shown that PVOD patients showed a higher cumulative tobacco exposure compared with idiopathic PAH patients. ${ }^{73}$ It is believed that tobacco and solvent exposure represent probably synergic effects in PVOD development. Interestingly, PAH patients, compared with healthy controls or chronic thromboembolic PH patients, showed a higher frequency of tobacco exposure. ${ }^{60}$ It is well established that tobacco exposure can result in endothelial dysfunction, ${ }^{81}$ which may directly induce pulmonary vascular remodeling in experimental $\mathrm{PH}$ models. ${ }^{82,83}$ However, it remains unclear why tobacco exposure appears to be more strongly associated with PVOD development, which predominantly affects the pulmonary venous and capillary compartments. Recently, it has been reported that exposure to alkylating agents in the setting of chemotherapy (eg, cyclophosphamide or mitomycin) may trigger PVOD development. This is supported by preclinical studies and evidence from human reports. ${ }^{46,61}$

\section{Prevention Strategies}

Regarding prevention strategies in PVOD, encouraging results were obtained in an animal model of PVOD induced by MMC. It was demonstrated that amifostine, given 30 minutes before MMC administration in rats, improved hemodynamic parameters and survival. ${ }^{45,61}$ Amifostine was tested because this molecule has been shown to decrease the frequency of cisplatin-induced nephrotoxicity, ototoxicity, neurotoxicity, and myelosuppression. This agent is able to reduce the hematological toxicity of cyclophosphamide, carboplatin, mitomycin, and antineoplastic drug 
combinations. ${ }^{84}$ At a mechanistic point of view, amifostine is a prodrug converted by alkaline phosphatase to the active sulfhydryl compound WR-1065. WR-1065 protects normal cells by scavenging free radicals, donating hydrogen ions to free radicals, depleting oxygen, and binding to active derivatives of antineoplastic agents.

\section{Treatment}

PVOD is a rare and chronic, progressive disease. Medical treatment options are limited, and further research is needed to develop new and innovative treatment options. In general, symptomatic treatment includes the cautious off-label use of $\mathrm{PAH}$-specific therapy. However, PAH-specific therapy may be responsible for pulmonary edema, and high doses of diuretics are often needed to prevent this complication. Clinical and hemodynamic assessments after the initiation of PAH therapies were reported in 64 patients from our center (17 EIF2AK4 mutations carriers and 47 noncarriers). Only three PVOD patients reached the predefined criteria for satisfactory clinical response in follow-up after PAH medical treatment initiation. ${ }^{74}$ After a median delay of 1 month, drug-induced pulmonary edema occurred in $23 \%$ of EIF $2 A K 4$ mutation carriers and in $21 \%$ of noncarriers. ${ }^{74}$ Among them, three patients were hospitalized in the intensive care unit for developing severe pulmonary edema and listed for urgent lung transplantation. The use of oral steroids has been attempted in selected cases, but no study has demonstrated efficacy.

\section{Outcome}

Outcome data regarding PVOD are scare. Holcomb et $\mathrm{al}^{85}$ reported $72 \%$ mortality within 1 year. A study from 2008 estimated the mean time from diagnosis to death or lung transplantation to be $11.8 \pm 16.4$ months. $^{73}$ The French PH Network recently demonstrated estimated 1-, 2-, and 3-year transplant-free survival probabilities of $63 \%, 52 \%$, and $32 \%$, respectively, in PVOD patients carrying the EIF2AK4 biallelic mutations. ${ }^{74}$ Results were similar in noncarriers, with estimated 1-, 2-, and 3-year transplant-free survival rates of $75 \%, 44 \%$, and $34 \%$, respectively. In noncarriers of EIF2AK4 mutations, $60 \%$ died after a median follow-up of 19 months and $21 \%$ received lung transplantation after a median delay of 9 months. The probabilities of event-free survival (death or transplantation) at 1 and 3 years were $63 \%$ and $32 \%$, respectively, in EIF2AK4 mutation carriers. Lung transplantation remains the definitive therapy, but only highly selected patients are eligible. Selection of patients depends on age of patients, associated comorbidities, and underlying disease severity.

\section{Animal Model}

A high-dose monocrotaline $(160 \mathrm{mg} / \mathrm{kg})$ injection in rats induces acute HVOD. Low-dose MCT $(60 \mathrm{mg} / \mathrm{kg})$ induces pulmonary vascular remodeling. Although the MCTinduced pulmonary vascular disease in the rat has been an accepted animal model of PAH-like disease, Wilson et $\mathrm{al}^{86}$ demonstrated the involvement of both small arteries and veins in the MCT model and questioned its usefulness as a model of PAH, which is mainly a precapillary disease. In their study, intra-acinar veins developed intimal plaques of smooth muscle in a collagenous matrix and accumulation of mononuclear inflammatory cells in the adventitial sheath of the small intra-acinar vessels. This change occurs in both pulmonary arteries and veins and is associated with or precedes the apparent accumulation of edema fluid in the adventitia and precedes the evidence of smooth muscle hypertrophy in the media of small arteries and the subintima of veins. A related report showed increased mitogenic activity, as evidenced by thymidine incorporation, by endothelial cells in both arteries and veins. ${ }^{87}$ Nonetheless, these post-capillary alterations are subtle compared with the strong arterial remodeling occurring in this model that is, therefore, not recognized as a suitable model of PVOD.

Recently, a specific animal model of PVOD after exposure to MMC was described. ${ }^{61}$ Male and female rats developed pulmonary hypertension 24 days after exposure to a single dose of $4 \mathrm{mg} / \mathrm{kg}$ MMC. A significant increase in mean pulmonary arterial hypertension pressure and total pulmonary resistance was observed, and cardiac output was decreased. ${ }^{61}$ Histologic analysis confirmed severe pulmonary vascular remodeling, which included the following: i) smooth muscle cell hypertrophy/hyperplasia in pulmonary arteries; ii) neomuscularization of the small distal and normally not muscularized pulmonary vessels; iii) vasculitis of the pulmonary arteries and veins; iv) foci of pulmonary edema and capillaritis; and v) foci of alveolar wall thickening, similar to pulmonary capillary hemangiomatosis. ${ }^{61}$ These histologic abnormalities are comparable to those described in human PVOD. In addition, we demonstrated that exposure to cyclophosphamide induces pulmonary hypertension in three different animal species: mouse, rat, and rabbit. ${ }^{45}$ At least lungs from rabbits exposed to cyclophosphamide represented histologic characteristics mimicking human PVOD. ${ }^{45}$

\section{Comparison of HVOD and PVOD}

The present review aimed to show similarities and differences (Table 3).

Incidence data are varying, depending on used criteria diagnosing HVOD. The mean incidence of HVOD after HSCT using the Seattle criteria was $17.3 \%$. In contrast, using the Baltimore criteria, the mean incidence was 9.6\%, reflecting the increased stringency of the Baltimore criteria for HVOD diagnosis. Incidence data in pyrrolizidine alkaloid HVOD or sinusoidal changes after chemotherapy for liver metastases are scare. Incidence data in patients presenting idiopathic PVOD are estimated to be 0.1 to 0.2 cases 
per million, and approximately 4 per 1000 patients develop PVOD after treatment with mitomycin after treatment for anal cancer.

Regarding disease pathogenesis, HVOD is characterized by nonthrombotic obstruction of the sinusoids; and in severe HVOD, subendothelial deposition of fibrous tissue in sinusoids and central and sublobular veins could be observed. On the contrary, the knowledge of PVOD pathogenesis remains limited, although a genetic implication (EIF2AK4 biallelic mutations) has been demonstrated ${ }^{58}$ and inflammation is likely to be implicated.

Genetic mutations are described in both entities, but no common abnormality has been identified for both conditions. In terms of risk factors, a common inciting trigger for HVOD and PVOD is exposure to toxic drugs, most notably represented by alkylating or alkylating-like agents, such as cyclophosphamide, mitomycin, carmustine, and dacarbazine. HVOD development after exposure to chemotherapy is a well-established complication of HSCT. However, the conditioning regimen in the setting of HVOD contains several drugs and, therefore, distinguishing the most likely culprit agent is difficult. Although anecdotal cases of chemotherapy-induced PVOD have been reported, it is not until recently that this clinical entity has received greater attention. ${ }^{88-90}$

In the context of HSCT-associated HVOD, clinical symptoms are observed during the first 30 days after exposure to chemotherapeutic drugs. In HVOD after chemotherapy for liver metastasis, clinical symptoms are often mild or absent. In chemotherapy-induced PVOD, diagnosis is delayed by 3 to 4 months after exposure to chemotherapeutic agents and lasts several decades after exposure to organic solvents.

Monocrotaline, a pyrrolizidine alkaloid, causes venoocclusive disease of the liver and pulmonary lesions in a dose-dependent manner within the same animal species. ${ }^{91}$ Studies showed that MCT induced acute HVOD/sinusoidal obstruction syndrome after administration of $160 \mathrm{mg}$ of monocrotaline, ${ }^{53}$ whereas $60 \mathrm{mg}$ of MCT induces delayed pulmonary vascular lesions ${ }^{92}$ and impaired repair capacities of pulmonary endothelial cells. The administration of a high dose of monocrotaline in animal models leads to hepatocyte necrosis, and clinical complications occur rapidly. The administration of a lower dose of monocrotaline or mitomycin is responsible for PVOD development, which may compromise the capacity for replicative repair of endothelial cells, accounting for the delayed vascular injury induced by these molecules. ${ }^{61}$

Indeed, pulmonary endothelial cells exposed to monocrotaline pyrrole (the active form of monocrotaline) exhibit cross-linking of DNA, such that cells cannot respond to the stimulus with cell division. Instead, cells spread to cover the small defects in the monolayer. With continued cell death, larger defects in the monolayer occur, which provide an even greater stimulus for cell division, but cells are still unable to replicate. Thus, a vicious cycle ensues in which larger and larger defects are produced. This cycle would explain why injury after MCT administration is delayed and progressive, with cell spreading initially to cover defects in the monolayers, in an attempt to delay the onset of vascular leak. Continuing cell death and the consequent enlargement of monolayer defects in the face of inhibited replicative repair result ultimately in vascular leak and denuded areas of vascular intima that favor the activation of platelets. In addition, the binding of monocrotaline pyrrole to DNA might alter the expression of critical genes. All these factors continue to reduce fibrinolytic activity (eg, by increasing the expression of plasminogen activator inhibitor), which would favor local thrombosis and obliteration of the vascular lumen. Growth factors, released by activated platelets and/or from affected endothelium, leak into the interstitium and may participate in the vascular remodeling. ${ }^{93}$ Similar mechanisms are operational in alkylating agent-induced PVOD and possibly also in radiation therapy-induced PVOD. ${ }^{94}$

Concerning the diagnostic approach, a noninvasive method is favored as patients with PVOD are often critically ill with severe PH. Lung biopsies are never performed to avoid respiratory failure or bleeding complications. In contrast, transjugular biopsy is a safe and useful tool in HVOD. No biomarker has been identified to facilitate the diagnosis of HVOD or PVOD.

Regarding prevention strategies in the setting of HVOD, recently updated guidelines suggest the use of UDCA. Amifostine, a cytoprotective adjuvant given in rats before exposure to dactinomycin in HVOD or in mitomycininduced PVOD, showed encouraging results in animal models to prevent either hepatic or pulmonary VOD. ${ }^{54,61}$

Supportive treatment options are available in PVOD, which include oxygen, high-dose diuretics, and cautious offlabel use of PAH-specific therapy in selected patients. Lung transplantation remains the treatment of choice but is reserved to a minority only. ${ }^{60}$

HVOD resolves spontaneously in $>80 \%$ of cases, whereas PVOD is irreversible in all cases. The European Commission gave a negative opinion in March 2013 regarding the prophylactic use of defibrotide, and the therapeutic use of defibrotide is still debated for severe HVOD. Liver transplantation is considered only in some patients who develop HVOD without an underlying malignant disease. ${ }^{95}$

\section{Perspectives}

Recent studies showed that PVOD development might be a consequence after chemotherapeutic treatment, especially after administration of alkylating agents. ${ }^{45,61}$ Cardiovascular toxicity after chemotherapeutic treatments for various malignancies is of increasing concern, which highlights the need to follow-up these patients regularly. It further highlights the need to strengthen the collaboration between cardiologists, chest physicians, internists, and oncologists. Prevention and treatment strategies should be optimized. Therefore, 
biomarkers should be tested systematically in patients at diagnosis of cancer and for follow-up after anticancer drug therapy. Cardiovascular biomarkers could include troponin I, $\mathrm{N}$-terminal probrain natriuretic peptide, cystatin $\mathrm{C}$, and C-reactive protein, as shown by Zethelius et al. ${ }^{96}$ Echocardiography should be performed systematically to rule out cardiac dysfunction and in the case of detected abnormalities; right-sided heart catheterization should be used to confirm the presence of $\mathrm{PH}$. Patients, regarding both entities, should be managed in expert centers where sufficient knowledge is available to cope with complications of these entities. The centralization of affected patients in expert centers also allows the attainment of further experiences regarding disease parameters, which permit eventually the identification of prognostic markers. Further fundamental research is needed to better understand the underlying mechanism for VOD development. Advances in the understanding of the pathophysiology of HVOD can be useful to better understand the pathophysiology of PVOD and vice versa. Indeed, the role of GCN2 dysfunction in the venular alteration of PVOD should be studied in the setting of HVOD. Defibrotide, the only approved treatment option in HVOD, could be tested in the mitomycin-induced PVOD animal model.

\section{Conclusions}

HVOD is characterized by a nonthrombotic obstruction of the sinusoids, whereas PVOD is characterized by increasing occlusion of pulmonary veins by fibrous tissue and intimal thickening. Only a few common features are identified, including several chemotherapeutic drugs favoring venoocclusive disease in both settings, mainly represented by cyclophosphamide, mitomycin, carmustine, and dacarbazine. However, both entities share less common points, as their denomination might suggest. The main clinical difference is the fact that PVOD is irreversible in all cases and HVOD resolved spontaneously in $80 \%$ of cases. Both conditions are relatively rare, and treatment options are scarce. Patients with severe HVOD might be eligible for treatment with defibrotide. No approved drug is available for PVOD. Defibrotide could be tested in an animal model of PVOD to evaluate its effects on the pulmonary vasculature.

\section{References}

1. Coppell JA, Richardson PG, Soiffer R, Martin PL, Kernan NA, Chen A, Guinan E, Vogelsang G, Krishnan A, Giralt S, Revta C, Carreau NA, Iacobelli M, Carreras E, Ruutu T, Barbui T, Antin JH, Niederwieser D: Hepatic veno-occlusive disease following stem cell transplantation: incidence, clinical course, and outcome. Biol Blood Marrow Transplant 2010, 16:157-168

2. Shulman HM, McDonald GB, Matthews D, Doney KC, Kopecky KJ, Gauvreau JM, Thomas ED: An analysis of hepatic venocclusive disease and centrilobular hepatic degeneration following bone marrow transplantation. Gastroenterology 1980, 79:1178-1191
3. Jones RJ, Lee KS, Beschorner WE, Vogel VG, Grochow LB, Braine HG, Vogelsang GB, Sensenbrenner LL, Santos GW, Saral R: Venoocclusive disease of the liver following bone marrow transplantation. Transplantation 1987, 44:778-783

4. McDonald GB, Sharma P, Matthews DE, Shulman HM, Thomas ED: Venocclusive disease of the liver after bone marrow transplantation: diagnosis, incidence, and predisposing factors. Hepatology 1984, 4: $116-122$

5. Carreras E, Díaz-Beyá M, Rosiñol L, Martínez C, FernándezAvilés F, Rovira M: The incidence of veno-occlusive disease following allogeneic hematopoietic stem cell transplantation has diminished and the outcome improved over the last decade. Biol Blood Marrow Transplant 2011, 17:1713-1720

6. Valla D-C, Cazals-Hatem D: Sinusoidal obstruction syndrome. Clin Res Hepatol Gastroenterol 2016, 40:378-385

7. Viganò L, Capussotti L, De Rosa G, De Saussure WO, Mentha G, Rubbia-Brandt L: Liver resection for colorectal metastases after chemotherapy: impact of chemotherapy-related liver injuries, pathological tumor response, and micrometastases on long-term survival. Ann Surg 2013, 258:731-740. discussion 741-742

8. Kumar S, DeLeve LD, Kamath PS, Tefferi A: Hepatic veno-occlusive disease (sinusoidal obstruction syndrome) after hematopoietic stem cell transplantation. Mayo Clin Proc 2003, 78:589-598

9. Mohty M, Malard F, Abecassis M, Aerts E, Alaskar AS, Aljurf M, Arat M, Bader P, Baron F, Bazarbachi A, Blaise D, Ciceri F, Corbacioglu S, Dalle J-H, Duarte RF, Fukuda T, Huynh A, Masszi T, Michallet M, Nagler A, NiChonghaile M, Pagluica T, Peters C, Petersen FB, Richardson PG, Ruutu T, Savani BN, Wallhult E, Yakoub-Agha I, Carreras E: Sinusoidal obstruction syndrome/venoocclusive disease: current situation and perspectives: a position statement from the European Society for Blood and Marrow Transplantation (EBMT). Bone Marrow Transplant 2015, 50:781-789

10. Wingard JR, Niehaus CS, Peterson DE, Jones RJ, Piantadosi S, Levin LS, Saral R, Santos GW: Oral mucositis after bone marrow transplantation: a marker of treatment toxicity and predictor of hepatic veno-occlusive disease. Oral Surg Oral Med Oral Pathol 1991, 72: 419-424

11. Fan CQ, Crawford JM: Sinusoidal obstruction syndrome (hepatic veno-occlusive disease). J Clin Exp Hepatol 2014, 4:332-346

12. Richardson PG, Grupp SA, Pagliuca A, Krishnan A, Ho VT, Corbacioglu S: Defibrotide for the treatment of hepatic venoocclusive disease/sinusoidal obstruction syndrome with multiorgan failure. Int J Hematol Oncol 2017, 6:75-93

13. Carreras E, Diaz-Ricart M: The role of the endothelium in the shortterm complications of hematopoietic SCT. Bone Marrow Transplant 2011, 46:1495-1502

14. DeLeve LD, Shulman HM, McDonald GB: Toxic injury to hepatic sinusoids: sinusoidal obstruction syndrome (veno-occlusive disease). Semin Liver Dis 2002, 22:27-42

15. Robinson SM, Mann J, Vasilaki A, Mathers J, Burt AD, Oakley F, White SA, Mann DA: Pathogenesis of FOLFOX induced sinusoidal obstruction syndrome in a murine chemotherapy model. J Hepatol 2013, 59:318-326

16. Marzano C, Cazals-Hatem D, Rautou P-E, Valla D-C: The significance of nonobstructive sinusoidal dilatation of the liver: impaired portal perfusion or inflammatory reaction syndrome. Hepatology 2015, 62:956-963

17. Vion A-C, Rautou P-E, Durand F, Boulanger CM, Valla DC: Interplay of inflammation and endothelial dysfunction in bone marrow transplantation: focus on hepatic veno-occlusive disease. Semin Thromb Hemost 2015, 41:629-643

18. Sato Y, Asada Y, Hara S, Marutsuka K, Tamura K, Hayashi T, Sumiyoshi A: Hepatic stellate cells (Ito cells) in veno-occlusive disease of the liver after allogeneic bone marrow transplantation. Histopathology 1999, 34:66-70

19. Nürnberger W, Michelmann I, Burdach S, Göbel U: Endothelial dysfunction after bone marrow transplantation: increase of soluble 
thrombomodulin and PAI-1 in patients with multiple transplantrelated complications. Ann Hematol 1998, 76:61-65

20. Salat C, Holler E, Kolb HJ, Pihusch R, Reinhardt B, Hiller E: Endothelial cell markers in bone marrow transplant recipients with and without acute graft-versus-host disease. Bone Marrow Transplant 1997, 19:909-914

21. Mahgerefteh SY, Sosna J, Bogot N, Shapira MY, Pappo O, Bloom AI: Radiologic imaging and intervention for gastrointestinal and hepatic complications of hematopoietic stem cell transplantation. Radiology 2011, 258:660-671

22. Lassau N, Leclère J, Auperin A, Bourhis JH, Hartmann O, ValteauCouanet D, Benhamou E, Bosq J, Ibrahim A, Girinski T, Pico JL, Roche A: Hepatic veno-occlusive disease after myeloablative treatment and bone marrow transplantation: value of gray-scale and Doppler US in 100 patients. Radiology 1997, 204:545-552

23. Brown BP, Abu-Yousef M, Farner R, LaBrecque D, Gingrich R: Doppler sonography: a noninvasive method for evaluation of hepatic venocclusive disease. AJR Am J Roentgenol 1990, 154:721-724

24. Erturk SM, Mortelé KJ, Binkert CA, Glickman JN, Oliva M-R, Ros PR, Silverman SG: CT features of hepatic venoocclusive disease and hepatic graft-versus-host disease in patients after hematopoietic stem cell transplantation. AJR Am J Roentgenol 2006, 186:1497-1501

25. Ward J, Guthrie JA, Sheridan MB, Boyes S, Smith JT, Wilson D, Wyatt JI, Treanor D, Robinson PJ: Sinusoidal obstructive syndrome diagnosed with superparamagnetic iron oxide-enhanced magnetic resonance imaging in patients with chemotherapy-treated colorectal liver metastases. J Clin Oncol 2008, 26:4304-4310

26. O'Rourke TR, Welsh FKS, Tekkis PP, Lyle N, Mustajab A, John TG, Peppercorn D, Rees M: Accuracy of liver-specific magnetic resonance imaging as a predictor of chemotherapy-associated hepatic cellular injury prior to liver resection. Eur J Surg Oncol 2009, 35: 1085-1091

27. Gauthé M, Bozec L, Bedossa P: Diagnosis of sinusoidal obstruction syndrome by positron emission tomography/computed tomography: report of two cases treated by defibrotide. Hepatology 2014, 60: $1789-1791$

28. Park SH, Lee SS, Sung J-Y, Na K, Kim HJ, Kim SY, Park BJ, Byun JH: Noninvasive assessment of hepatic sinusoidal obstructive syndrome using acoustic radiation force impulse elastography imaging: a proof-of-concept study in rat models. Eur Radiol 2018, 28: 2096-2106

29. Auberger J, Graziadei I, Clausen J, Vogel W, Nachbaur D: Noninvasive transient elastography for the prediction of liver toxicity following hematopoietic SCT. Bone Marrow Transplant 2013, 48: $159-160$

30. Carreras E, Grañena A, Navasa M, Bruguera M, Marco V, Sierra J, Tassies MD, García-Pagán JC, Martí JM, Bosch J: Transjugular liver biopsy in BMT. Bone Marrow Transplant 1993, 11:21-26

31. Shulman HM, Gooley T, Dudley MD, Kofler T, Feldman R, Dwyer D, McDonald GB: Utility of transvenous liver biopsies and wedged hepatic venous pressure measurements in sixty marrow transplant recipients. Transplantation 1995, 59:1015-1022

32. Nadolski G, Mondschein JI, Shlansky-Goldberg RD, Stavropoulos SW, Soulen MC, Dagli MS, Clark TWI, Trerotola SO: Diagnostic yield of transjugular liver biopsy samples to evaluate for infectious etiology of liver dysfunction in bone marrow transplant recipients. Cardiovasc Intervent Radiol 2014, 37:471-475

33. Ahmed O, Ward TJ, Lungren MP, Abdelrazek Mohammed MA, Hofmann LV, Sze DY, Kothary N: Assessing the risk of hemorrhagic complication following transjugular liver biopsy in bone marrow transplantation recipients. J Vasc Interv Radiol 2016, 27: $551-557$

34. Carreras E: How I manage sinusoidal obstruction syndrome after haematopoietic cell transplantation. Br J Haematol 2015, 168: 481-491

35. Vukelja SJ, Baker WJ, Jeffreys P, Reeb BA, Pick T: Nonbacterial thrombotic endocarditis clinically mimicking veno-occlusive disease of the liver complicating autologous bone marrow transplantation. Am J Clin Oncol 1992, 15:500-502

36. Srivastava A, Poonkuzhali B, Shaji RV, George B, Mathews V, Chandy M, Krishnamoorthy R: Glutathione S-transferase M1 polymorphism: a risk factor for hepatic venoocclusive disease in bone marrow transplantation. Blood 2004, 104:1574-1577

37. Kallianpur AR, Hall LD, Yadav M, Byrne DW, Speroff T, Dittus RS, Haines JL, Christman BW, Summar ML: The hemochromatosis C282Y allele: a risk factor for hepatic veno-occlusive disease after hematopoietic stem cell transplantation. Bone Marrow Transplant 2005, 35:1155-1164

38. Mellis C, Bale PM: Familial hepatic venoocclusive disease with probable immune deficiency. J Pediatr 1976, 88:236-242

39. Wang T, Ong P, Roscioli T, Cliffe ST, Church JA: Hepatic venoocclusive disease with immunodeficiency (VODI): first reported case in the U.S. and identification of a unique mutation in Sp110. Clin Immunol 2012, 145:102-107

40. Cliffe ST, Bloch DB, Suryani S, Kamsteeg E-J, Avery DT, Palendira U, Church JA, Wainstein BK, Trizzino A, Lefranc G, Akatcherian C, Megarbané A, Gilissen C, Moshous D, Reichenbach J, Misbah S, Salzer U, Abinun M, Ong PY, Stepensky P, Ruga E, Ziegler JB, Wong M, Tangye SG, Lindeman R, Buckley MF, Roscioli T: Clinical, molecular, and cellular immunologic findings in patients with SP110-associated veno-occlusive disease with immunodeficiency syndrome. J Allergy Clin Immunol 2012, 130:735-742.e6

41. Roscioli T, Cliffe ST, Bloch DB, Bell CG, Mullan G, Taylor PJ, Sarris M, Wang J, Donald JA, Kirk EP, Ziegler JB, Salzer U, McDonald GB, Wong M, Lindeman R, Buckley MF: Mutations in the gene encoding the PML nuclear body protein Sp110 are associated with immunodeficiency and hepatic veno-occlusive disease. Nat Genet 2006, 38:620-622

42. McDonald GB, Hinds MS, Fisher LD, Schoch HG, Wolford JL, Banaji M, Hardin BJ, Shulman HM, Clift RA: Veno-occlusive disease of the liver and multiorgan failure after bone marrow transplantation: a cohort study of 355 patients. Ann Intern Med 1993, 118: 255-267

43. DeLeve LD, Valla D-C, Garcia-Tsao G; American Association for the Study Liver Diseases: Vascular disorders of the liver. Hepatology 2009, 49:1729-1764

44. Corbacioglu S, Cesaro S, Faraci M, Valteau-Couanet D, Gruhn B, Rovelli A, et al: Defibrotide for prophylaxis of hepatic veno-occlusive disease in paediatric haemopoietic stem-cell transplantation: an openlabel, phase 3, randomised controlled trial. Lancet 2012, 379: 1301-1309

45. Ranchoux B, Günther S, Quarck R, Chaumais M-C, Dorfmüller P, Antigny F, Dumas SJ, Raymond N, Lau E, Savale L, Jaïs X, Sitbon O, Simonneau G, Stenmark K, Cohen-Kaminsky S, Humbert M, Montani D, Perros F: Chemotherapy-induced pulmonary hypertension: role of alkylating agents. Am J Pathol 2015, 185: 356-371

46. Tandon RK, Tandon BN, Tandon HD, Bhatia ML, Bhargava S, Lal P, Arora RR: Study of an epidemic of venoocclusive disease in India. Gut 1976, 17:849-855

47. Dignan FL, Wynn RF, Hadzic N, Karani J, Quaglia A, Pagliuca A, Veys P, Potter MN; Haemato-oncology Task Force of British Committee for Standards in Haematology; British Society for Blood and Marrow Transplantation: BCSH/BSBMT guideline: diagnosis and management of veno-occlusive disease (sinusoidal obstruction syndrome) following haematopoietic stem cell transplantation. $\mathrm{Br} \mathrm{J}$ Haematol 2013, 163:444-457

48. Ruutu T, Juvonen E, Remberger M, Remes K, Volin L, Mattsson J, Nihtinen A, Hägglund H, Ringdén O; Nordic Group for Blood and Marrow Transplantation: Improved survival with ursodeoxycholic acid prophylaxis in allogeneic stem cell transplantation: long-term follow-up of a randomized study. Biol Blood Marrow Transplant 2014, 20:135-138 
49. Ruutu T, Eriksson B, Remes K, Juvonen E, Volin L, Remberger M, Parkkali T, Hägglund H, Ringdén O; Nordic Bone Marrow Transplantation Group: Ursodeoxycholic acid for the prevention of hepatic complications in allogeneic stem cell transplantation. Blood 2002, 100:1977-1983

50. Richardson PG, Riches ML, Kernan NA, Brochstein JA, Mineishi S, Termuhlen AM, Arai S, Grupp SA, Guinan EC, Martin PL, Steinbach G, Krishnan A, Nemecek ER, Giralt S, Rodriguez T, Duerst R, Doyle J, Antin JH, Smith A, Lehmann L, Champlin R, Gillio A, Bajwa R, D'Agostino RB, Massaro J, Warren D, Miloslavsky M, Hume RL, Iacobelli M, Nejadnik B, Hannah AL, Soiffer RJ: Phase 3 trial of defibrotide for the treatment of severe veno-occlusive disease and multi-organ failure. Blood 2016, 127: $1656-1665$

51. Al Beihany A, Al Omar H, Sahovic E, Chaudhri N, Al Mohareb F, Al Sharif F, Al Zahrani H, Al Shanqeeti A, Seth P, Zaidi S, Morshed M, Al Anazi K, Mohamed G, Gyger M, Aljurf M: Successful treatment of hepatic veno-occlusive disease after myeloablative allogeneic hematopoietic stem cell transplantation by early administration of a short course of methylprednisolone. Bone Marrow Transplant 2008, 41:287-291

52. Carreras E, Bertz H, Arcese W, Vernant JP, Tomás JF, Hagglund H, Bandini G, Esperou H, Russell J, de la Rubia J, Di Girolamo G, Demuynck H, Hartmann O, Clausen J, Ruutu T, Leblond V, Iriondo A, Bosi A, Ben-Bassat I, Koza V, Gratwohl A, Apperley JF; European Group for Blood and Marrow Transplantation Chronic Leukemia Working Party: Incidence and outcome of hepatic venoocclusive disease after blood or marrow transplantation: a prospective cohort study of the European Group for Blood and Marrow Transplantation. Blood 1998, 92:3599-3604

53. DeLeve LD, McCuskey RS, Wang X, Hu L, McCuskey MK, Epstein RB, Kanel GC: Characterization of a reproducible rat model of hepatic veno-occlusive disease. Hepatology 1999, 29: $1779-1791$

54. Czauderna P, Chyczewski L, Lech K, Langner G, Bednarczuk G, Borowska H, Arciszewska E: Experimental model of hepatic venoocclusive disease (VOD) caused by dactinomycin: preliminary report about hepatoprotective effect of amifostine. Med Sci Monit 2000, 6:446-453

55. Simonneau G, Montani D, Celermajer DS, Denton CP, Gatzoulis MA, Krowka M, Williams PG, Souza R: Haemodynamic definitions and updated clinical classification of pulmonary hypertension. Eur Respir J 2019, 53:1801913

56. Höra J: [On the histology of clinical primary pulmonary sclerosis]. German. Frankf Z Pathol 1934, 47:100-108

57. Heath D, Segel N, Bishop J: Pulmonary veno-occlusive disease. Circulation 1966, 34:242-248

58. Eyries M, Montani D, Girerd B, Perret C, Leroy A, Lonjou C, Chelghoum N, Coulet F, Bonnet D, Dorfmüller P, Fadel E, Sitbon O, Simonneau G, Tregouët D-A, Humbert M, Soubrier F: EIF2AK4 mutations cause pulmonary veno-occlusive disease, a recessive form of pulmonary hypertension. Nat Genet 2014, 46:65-69

59. Best DH, Sumner KL, Austin ED, Chung WK, Brown LM, Borczuk AC, Rosenzweig EB, Bayrak-Toydemir P, Mao R, Cahill BC, Tazelaar HD, Leslie KO, Hemnes AR, Robbins IM, Elliott CG: EIF2AK4 mutations in pulmonary capillary hemangiomatosis. Chest 2014, 145:231-236

60. Montani D, Lau EM, Dorfmüller P, Girerd B, Jaïs X, Savale L, Perros F, Nossent E, Garcia G, Parent F, Fadel E, Soubrier F, Sitbon O, Simonneau G, Humbert M: Pulmonary veno-occlusive disease. Eur Respir J 2016, 47:1518-1534

61. Perros F, Günther S, Ranchoux B, Godinas L, Antigny F, Chaumais M-C, Dorfmüller P, Hautefort A, Raymond N, Savale L, Jaïs X, Girerd B, Cottin V, Sitbon O, Simonneau G, Humbert M, Montani D: Mitomycin-induced pulmonary veno-occlusive disease: evidence from human disease and animal models. Circulation 2015, 132:834-847
62. Pai VB, Nahata MC: Cardiotoxicity of chemotherapeutic agents: incidence, treatment and prevention. Drug Saf 2000, 22:263-302

63. Montani D, Lau EM, Descatha A, Jaïs X, Savale L, Andujar P, Bensefa-Colas L, Girerd B, Zendah I, Le Pavec J, Seferian A, Perros F, Dorfmüller P, Fadel E, Soubrier F, Sitbon O, Simonneau G, Humbert M: Occupational exposure to organic solvents: a risk factor for pulmonary veno-occlusive disease. Eur Respir J 2015, 46: $1721-1731$

64. McGoon MD, Benza RL, Escribano-Subias P, Jiang X, Miller DP, Peacock AJ, Pepke-Zaba J, Pulido T, Rich S, Rosenkranz S, Suissa S, Humbert M: Pulmonary arterial hypertension: epidemiology and registries. J Am Coll Cardiol 2013, 62:D51-D59

65. Larkin EK, Newman JH, Austin ED, Hemnes AR, Wheeler L, Robbins IM, West JD, Phillips JA, Hamid R, Loyd JE: Longitudinal analysis casts doubt on the presence of genetic anticipation in heritable pulmonary arterial hypertension. Am J Respir Crit Care Med 2012, 186:892-896

66. Bal E, Ilgin S, Atli O, Ergun B, Sirmagul B: The effects of gender difference on monocrotaline-induced pulmonary hypertension in rats. Hum Exp Toxicol 2013, 32:766-774

67. Perros F, Cohen-Kaminsky S, Gambaryan N, Girerd B, Raymond N, Klingelschmitt I, Huertas A, Mercier O, Fadel E, Simonneau G, Humbert M, Dorfmüller P, Montani D: Cytotoxic cells and granulysin in pulmonary arterial hypertension and pulmonary veno-occlusive disease. Am J Respir Crit Care Med 2013, 187:189-196

68. Marcos E, Fadel E, Sanchez O, Humbert M, Dartevelle P, Simonneau G, Hamon M, Adnot S, Eddahibi S: Serotonin-induced smooth muscle hyperplasia in various forms of human pulmonary hypertension. Circ Res 2004, 94:1263-1270

69. Kradin R, Matsubara O, Mark EJ: Endothelial nitric oxide synthase expression in pulmonary capillary hemangiomatosis. Exp Mol Pathol 2005, 79:194-197

70. Nossent EJ, Antigny F, Montani D, Bogaard HJ, Ghigna MR, Lambert M, Thomas de Montpréville V, Girerd B, Jaïs X, Savale L, Mercier O, Fadel E, Soubrier F, Sitbon O, Simonneau G, Vonk Noordegraaf A, Humbert M, Perros F, Dorfmüller P: Pulmonary vascular remodeling patterns and expression of general control nonderepressible 2 (GCN2) in pulmonary veno-occlusive disease. J Heart Lung Transplant 2018, 37:647-655

71. Wagenvoort CA, Wagenvoort N: The pathology of pulmonary venoocclusive disease. Virchows Arch A Pathol Anat Histol 1974, 364:69-79

72. Schraufnagel DE, Sekosan M, McGee T, Thakkar MB: Human alveolar capillaries undergo angiogenesis in pulmonary venoocclusive disease. Eur Respir J 1996, 9:346-350

73. Montani D, Achouh L, Dorfmüller P, Le Pavec J, Sztrymf B, Tchérakian C, Rabiller A, Haque R, Sitbon O, Jaïs X, Dartevelle P, Maître S, Capron F, Musset D, Simonneau G, Humbert M: Pulmonary veno-occlusive disease: clinical, functional, radiologic, and hemodynamic characteristics and outcome of 24 cases confirmed by histology. Medicine (Baltimore) 2008, 87:220-233

74. Montani D, Girerd B, Jaïs X, Levy M, Amar D, Savale L, Dorfmüller P, Seferian A, Lau EM, Eyries M, Le Pavec J, Parent F, Bonnet D, Soubrier F, Fadel E, Sitbon O, Simonneau G, Humbert M: Clinical phenotypes and outcomes of heritable and sporadic pulmonary veno-occlusive disease: a population-based study. Lancet Respir Med 2017, 5:125-134

75. Resten A, Maitre S, Humbert M, Rabiller A, Sitbon O, Capron F, Simonneau G, Musset D: Pulmonary hypertension: CT of the chest in pulmonary venoocclusive disease. AJR Am J Roentgenol 2004, 183: 65-70

76. Rabiller A, Jaïs X, Hamid A, Resten A, Parent F, Haque R, Capron F, Sitbon O, Simonneau G, Humbert M: Occult alveolar haemorrhage in pulmonary veno-occlusive disease. Eur Respir J 2006, 27:108-113

77. Sourla E, Paspala A, Boutou A, Kontou P, Stanopoulos I, Pitsiou G: A case of pulmonary veno-occlusive disease: diagnostic dilemmas and therapeutic challenges. Ther Adv Respir Dis 2013, 7:119-123 
78. Girerd B, Montani D, Jaïs X, Eyries M, Yaici A, Sztrymf B, Savale L, Parent F, Coulet F, Godinas L, Lau EM, Tamura Y, Sitbon O, Soubrier F, Simonneau G, Humbert M: Genetic counselling in a national referral centre for pulmonary hypertension. Eur Respir J 2016, 47:541-552

79. Overbeek MJ, Vonk MC, Boonstra A, Voskuyl AE, VonkNoordegraaf A, Smit EF, Dijkmans BA, Postmus PE, Mooi WJ, Heijdra Y, Grünberg K: Pulmonary arterial hypertension in limited cutaneous systemic sclerosis: a distinctive vasculopathy. Eur Respir J 2009, 34:371-379

80. Dorfmüller P, Humbert M, Perros F, Sanchez O, Simonneau G, Müller K-M, Capron F: Fibrous remodeling of the pulmonary venous system in pulmonary arterial hypertension associated with connective tissue diseases. Hum Pathol 2007, 38:893-902

81. Celermajer DS, Sorensen KE, Georgakopoulos D, Bull C, Thomas O, Robinson J, Deanfield JE: Cigarette smoking is associated with doserelated and potentially reversible impairment of endotheliumdependent dilation in healthy young adults. Circulation 1993, 88: 2149-2155

82. Wright JL, Churg A: Effect of long-term cigarette smoke exposure on pulmonary vascular structure and function in the guinea pig. Exp Lung Res 1991, 17:997-1009

83. Weissmann N, Grimminger F, Seeger W: Smoking: is it a risk factor for pulmonary vascular diseases? Pulm Circ 2012, 2:395-396

84. Foster-Nora JA, Siden R: Amifostine for protection from antineoplastic drug toxicity. Am J Health Syst Pharm 1997, 54: 787-800

85. Holcomb BW, Loyd JE, Ely EW, Johnson J, Robbins IM: Pulmonary veno-occlusive disease: a case series and new observations. Chest 2000, 118:1671-1679

86. Wilson DW, Segall HJ, Pan LC, Dunston SK: Progressive inflammatory and structural changes in the pulmonary vasculature of monocrotaline-treated rats. Microvasc Res 1989, 38:57-80
87. Meyrick BO, Reid LM: Crotalaria-induced pulmonary hypertension: uptake of 3H-thymidine by the cells of the pulmonary circulation and alveolar walls. Am J Pathol 1982, 106:84-94

88. Gagnadoux F, Capron F, Lebeau B: Pulmonary veno-occlusive disease after neoadjuvant mitomycin chemotherapy and surgery for lung carcinoma. Lung Cancer 2002, 36:213-215

89. Swift GL, Gibbs A, Campbell IA, Wagenvoort CA, Tuthill D: Pulmonary veno-occlusive disease and Hodgkin's lymphoma. Eur Respir J 1993, 6:596-598

90. Rose AG: Pulmonary veno-occlusive disease due to bleomycin therapy for lymphoma: case reports. S Afr Med J 1983, 64:636-638

91. Yan CC, Huxtable RJ: Effects of monocrotaline, a pyrrolizidine alkaloid, on glutathione metabolism in the rat. Biochem Pharmacol 1996, 51:375-379

92. Miyauchi T, Yorikane R, Sakai S, Sakurai T, Okada M, Nishikibe M, Yano M, Yamaguchi I, Sugishita Y, Goto K: Contribution of endogenous endothelin-1 to the progression of cardiopulmonary alterations in rats with monocrotaline-induced pulmonary hypertension. Circ Res 1993, 73:887-897

93. Reindel JF, Roth RA: The effects of monocrotaline pyrrole on cultured bovine pulmonary artery endothelial and smooth muscle cells. Am J Pathol 1991, 138:707-719

94. Kramer MR, Estenne M, Berkman N, Antoine M, de Francquen P, Lipski A, Jacobovitz D, Lafair J: Radiation-induced pulmonary venoocclusive disease. Chest 1993, 104:1282-1284

95. Kim I-D, Egawa H, Marui Y, Kaihara S, Haga H, Lin Y-W, Kudoh K, Kiuchi T, Uemoto S, Tanaka K: A successful liver transplantation for refractory hepatic veno-occlusive disease originating from cord blood transplantation. Am J Transplant 2002, 2:796-800

96. Zethelius B, Berglund L, Sundström J, Ingelsson E, Basu S, Larsson A, Venge P, Arnlöv J: Use of multiple biomarkers to improve the prediction of death from cardiovascular causes. N Engl J Med 2008, 358:2107-2116 